\title{
Formation of the trial jury in the period of the pandemic: Russian and foreign experience
}

\author{
Lydia Alekseevna Voskobitova $^{1^{*}}$, Tatiana Yurievna Vilkova $^{1}$, Sergei Aleksandrovich \\ Nasonov $^{1}$, Maksim Aleksandrovich Khokhryakov ${ }^{1}$, and Rifat Rahmadjon Rahmadjonzoda \\ (Rifat Rahmadjon Yuldoshev) $^{2}$ \\ ${ }^{1}$ Kutafin Moscow State Law University, Department of Criminal Procedure Law, Moscow, Russia \\ ${ }^{2}$ Academy of the Ministry of Internal Affairs of the Republic of Tajikistan, Faculty No. 1, Dushanbe, \\ Tajikistan
}

\begin{abstract}
The prerequisites for the research were formed by a complex collision between the legal nature of proceedings in the jury court and the standard sanitary and epidemiological restrictions. This collision was revealed in the course of the theoretical treatment of administration of justice in the pandemic period. The primary stage of judicial proceedings involving the participation of the jury was highlighted by the authors as a subject of the research - formation of the trial jury, where the said collision appears to be especially acute. The purpose of the study was to search for possible solutions to this collision; the objective - verification of the hypothesis stating that the pandemic situation has engendered a significant modification of the procedural form of trial jury selection. To resolve this problem, the normative approach, along with the method of legal comparative studies, was used: the criminal procedure legislation and the practice of its enforcement in the Russian Federation and a number of foreign countries was analysed. General logical methods were used: analysis and synthesis, induction and deduction, abstraction and progression from the abstract to the concrete, etc. The result of the research is the identification of special approaches in the Russian and foreign models of court proceedings involving the participation of the jury, reflecting the intention to adjust the procedure of trial jury formation to the pandemic period requirements: telecommuted formation of the trial jury in full or in part; replacing verbal questioning of candidates to the jury with a written questionnaire; extending the questioning of jury candidates through the inclusion of specific issues concerning the epidemiological situation. The hypothesis proposed in the publication was confirmed, in particular, relative to the Russian court proceedings with the participation of the jury.
\end{abstract}

Keywords: the jury, remote selection, asynchronous selection, COVID-19

\section{Introduction}

The development of the novel coronavirus infection pandemic (COVID-19) on a global scale has not only brought about objective changes in all spheres of public life but also inevitably

* Corresponding author: lavosk@mail.ru 
affected the legal framework of the administration of criminal justice. In these terms, the analysis of the impact of the pandemic situation on judicial proceedings involving the participation of the jury is of special interest, since a complex collision arises between the legal nature of this form of legal proceedings and the sanitary restrictions characteristic of the pandemic period. Court proceedings with the participation of the jury presuppose a significant increase in the number of participants of the trial in comparison with cases considered in the ordinary course (owing to the participation of the trial jury in the pleadings); extended duration of the process (due to its specific stages); the impossibility of radical limitation of unmediated examination of proof in court, etc. These features require special approaches to the realisation of sanitary and epidemiological restrictions and raise the need for modifying the order of court proceedings with the participation of the jury.

This modification should ensure the realisation of the essential features of litigation with the participation of the jury in the context of pandemic restrictions and should not contradict the principles of criminal proceedings and the general conditions of a particular stage of the process.

In this regard, the modification of the initial stage of court proceedings involving the participation of the jury is of particular interest - trial jury formation where this collision appears to be especially acute. The number of participants in a court session in one room reaches its maximum through attracting several dozen jury candidates in the process. The procedural mechanism of formation of the trial jury supposes a durable presence of a number of candidates in the same space of procedural actions; moreover, in the event of an insufficient number of candidates for the jury, different models of such proceedings provide for summoning additional candidates, thus increasing the risks specific of the pandemic period. Discussion of a number of questions, at the court premises, posed to jury candidates by the presiding official or the parties makes compliance with the social distancing requirement problematic. The resolution of this collision is of significant theoretical and practical importance for the perfection of court proceedings involving the participation of the jury, which sets the purpose of the given research that aims to verify the hypothesis asserting that the pandemic situation has led to the modification of the procedural form of trial jury selection which allows continued consideration of cases involving the participation of the jury in the pandemic period.

\section{$2 \quad$ Materials and methods}

To address the problem, the normative approach and the method of legal comparative studies were used: the criminal procedure legislation and the practice of its enforcement in the Russian Federation and a number of foreign countries were analysed. An analysis of doctrinal approaches developed in the Russian and foreign scientific literature in respect of possible change in the procedure for the formation of the trial jury was made. General logical methods were used: analysis and synthesis, induction and deduction, abstraction and progression from the abstract to the concrete, etc.

\section{Results}

The analysis of the legislation and the judicial practice allowed the authors to highlight the following approaches used in different states relative to the procedure of trial jury formation during the pandemic:

1) formation of the trial jury entirely in the remote mode (telecommuted asynchronous or synchronous selection of the jury). 
This modification, new for legal proceedings, supposes the use of online-version electronic questionnaires for candidates to the jury, with the answers collected in a single spreadsheet available to the parties. The range of issues highlighted in the electronic questionnaire includes, as proposed by the court, evaluation of access to technologies, difficulties and levels of risk inherent in COVID-19. The actual procedure for forming the trial jury takes place in a Zoom conferencing format. During the session, the candidates for the jury appear before the parties not simultaneously, but in small groups of 10-20 persons (at the discretion of the court). The time for interviewing candidates for the jury may be limited by the court. The jury candidates who are unwilling or unable to participate in video conferencing are given an opportunity to be present in person in court during the selection process, i.e. in the conditions providing due social distancing. However, most candidates for the jury are selected being interviewed from home or from their job place. This procedure is used in courts of the United States [1], Scotland [2], Canada [3], and Australia [4].

Some variation of using this survey method during peak periods of the pandemic are traced in the Russian jurisprudence, since the Presidium of the Russian Federation Supreme Court stated, in a review approved on April 30, 2020 [5], that the court has the right to organise the hearing of all criminal cases requiring urgent consideration, in part or in full, with the use of videoconferencing. Pursuant to this legal position of the RF Supreme Court, appeals against court sentences passed with the participation of the jury are not satisfied in the Russian judicial practice if a particular part of a court session (including trial jury formation) was held using remote methods (videoconferencing). An example of such a decision is the Appellate Ruling of the Supreme Court of the Republic of Sakha (Yakutia) as of September 8, 2020 under the case No. 22-1314/2020 [6].

At the same time, the current Russian legislation does not allow for asynchrony in the selection of the trial jury, which excludes the division of candidates for the jury into groups at the stage of interviewing, filing objections, etc. It seems that to secure a more efficient realisation of the remote format for the selection of the trial jury, relevant adjustments can be made to the provisions of Art. 238 of the Criminal Procedure Code of the Russian Federation;

2) Replacement of verbal questioning of jury candidates with scriptory interviewing.

In a number of foreign-court trial models with the participation of the jury, that provide for written questioning of candidates for the jury, the appearance of candidates for face-toface interviews is minimised (excluded) for the time of pandemic restrictions.

For instance, the Criminal Procedure Code of Georgia [7] provides for holding a special court session where the presiding official, after listening to the opinion of the parties, sets a stage of selection from the voter list and forms a list of jury candidates comprising 50 persons, which is handed over to the parties. At the said session, the court, taking into account the opinions of the parties, draws up a questionnaire, which is sent out to the jury candidates, with simultaneous notification about the place and time of the court session. The questions are formulated on the basis of proposals of the parties having the right to familiarise themselves with the candidates' answers, which fully compensates for the absence of a "faceto-face" stage in the formation of the trial jury.

It seems that this approach might also interesting for adapting the Russian trial jury formation model to the limitations of the pandemic period.

3) Extending the questioning of candidates for the jury through the inclusion of information aimed to reveal the fact of contamination of a candidate or his/her family members with a novel coronavirus infection.

There are examples in the Russian litigation practice, when candidates for the jury or their family members are found to be/have been infected with a new coronavirus infection, as revealed by the presiding official [6]. Seemingly, this fact can be highlighted by the presiding official only in the context of identifying the circumstances preventing a candidate from participating in the jury under a criminal case for a particular period. It is obvious that the 
participation of a person ill with COVID-19 as a jury member in a trial poses a threat to the health of all participants of the trial, so the candidacy of this person should be rejected. However, if the disease took place in the past and its consequences do not create any obstacles for the candidate to participate in the litigation as a jury member, then this information has no legal value and should not hamper the work of the jury candidate. It appears that this consideration should be set forth in a resolution of the RF Supreme Court Plenum which explains the specifics of court proceedings with the participation of the jury.

\section{Discussion}

The scrutiny of the relevant literature shows that the scientific analysis of the procedure for the formation of the trial jury in the conditions of a pandemic is in its infancy.

However, the introduction of special procedural and organisational rules for this stage of judicial activity involving the participation of the jury should take place with regard for general approaches aimed to ensure the balance of restrictive measures necessary to maintain the due composition of the jury and the need to preserve the principles of criminal proceedings.

The issues under consideration were dwelled upon in a number of essays emphasising that the emergency measures applied in legal proceedings in the conditions of the spread of the coronavirus infection should be enforced on the principles of the rule of law, respect for human rights, legality, juridical security, and commensuration [8].

It is generally recognised that the use of digital technologies meets these requirements to the greatest extent, including the organisation of off-site court hearings and the interaction of all participants in the criminal process in a paper-free format [9-13]. This allows for due enforcement of justice and secures confidence in the judiciary system in the conditions when courts have to suspend litigation of certain cases $[14,15]$. Remote-mode or hybrid court sessions are practiced in pleading cases not only in the first instance litigation but also in the appellate instance [16].

However, replacing traditional litigation with telecommuting should not be applied as a general and perpetual rule [17]. For instance, the possibility of remote imposition of capital punishment has been hotly debated [18].

\section{Conclusion}

Thus, the hypothesis suggested in this publication has been confirmed, including in relation to the Russian litigation with the participation of the jury. However, the deficiency of legislative regulation of these procedural features in the Criminal Procedure Code of the Russian Federation does not make it possible to fully compensate for all restrictions conditioned by the pandemic situation. In this regard, the considered approaches to statutory regulation of such procedural modifications, as introduced in foreign models, are of specific interest.

The publication was prepared within the framework of the governmental assignment 075-00293-20-02 of 25.05.2020 "Transformation of the Russian law in the face of great challenges: theoretical and applied foundations". Subject number - FSMW-2020-0030.

\section{References}

1. G.B. Hunter, A.B. Hunter, Remote jury selection in Seattle: the new, the improved, and the familiar (2020). Accessed on: March 22, 2021. [Online]. Available: 
https://myemail.constantcontact.com/October-Newsletter-of-the-Civil-JuryProject.html? soid=1127815376566\&aid=5F82JDkSMPs

2. D. Cowan, Coronavirus: High Court trials to resume with distanced jurors (2020). Accessed on: March 22, 2021. [Online]. Available: https://www.bbc.com/news/ukscotland-53423373

3. Y. Bergeron, Un premier procèsdevant jury à Québec en temps de pandémie (2020). Accessed on: March 22, 2021. [Online]. Available: https://ici.radiocanada.ca/nouvelle/1732357/proces-jury-pandemie-palais-justice

4. A. Cooper, Jury trials to return to Victoria in 2020 (2020). Accessed on: March 22, 2021. [Online]. Available: https://www.theage.com.au/national/victoria/jury-trials-toreturn-to-victoria-in-2020-20201021-p5672h.html

5. Presidium of the Supreme Court of the Russian Federation, Obzor po otdelnym voprosam sudebnoi praktiki, svyazannym s primeneniem zakonodatelstva i mer po protivodeistviyu rasprostraneniyu na territorii Rossiiskoi Federatsii novoi koronavirusnoi infektsii (COVID-19) No. 2 [Review on selected issues of judicial practice related to the enforcement of legislation and measures to counter the spread of a new coronavirus infection (COVID-19) No. 2 in the Russian Federation] (Moscow, April 30, 2020). Accessed on: March 22, 2021. [Online]. Available: https://www.vsrf.ru/documents/all/28882/

6. Apellyatsionnoe opredelenie Verkhovnogo suda Respubliki Sakha (Yakutiya) ot 08.09.20 po delu 22-1314 [Appeal ruling of the Supreme Court of the Republic of Sakha (Yakutia) in case No. 22-1314] (2020, September 8)

7. Ugolovno-protsessualnyi kodeks Gruzii No. 1772 [Criminal Procedure Code of Georgia No. 1772] (2009, October 9) (as amended on July 15, 2020 No. 6949). Accessed on: March 22, 2021. [Online]. Available: https://matsne.gov.ge/ru/document/view/90034?publication=124

8. O.I. Andreeva, O.V. Kachalova, Tomsk State University Journal of Law, 36, 5-15 (2020). https://doi.org/10.17223/22253513/36/1

9. O.I. Andreeva, O.A. Zaycev, A.V. Kudryavceva, Russian Journal of Criminology 14(5), 786-797 (2020). https://doi.org/10.17150/2500-4255.2020.14(5).786-797

10. I. Freckelton, J. Law Med. 27(4), 790-806 (2020). Accessed on: March 22, 2021. [Online]. Available: https://pubmed.ncbi.nlm.nih.gov/32880398/

11. M. Legg, A. Song, Aust. Bus. Law Rev. 48(2), 159-168 (2020)

12. T.Y. Vilkova, L.N. Maslennikova, Perm University Herald. Juridical Sciences, 46, 728-751 (2019). https://doi.org/10.17072/1995-4190-2019-46-728-751

13. R.H. Warner, Fam. Court Rev. 58(4), 965-967 (2020). https://doi.org/10.1111/fcre.12529

14. O. Kaplina, S. Sharenko, Access to Justice in Eastern Europe, 2/3(7), 115-133 (2020). https://doi.org/10.33327/AJEE-18-3.2-3

15. T. Sourdin, B. Li, D.M. McNamara, Health Policy Technol. 9(4), 447-453 (2020). https://doi.org/10.1016/j.hlpt.2020.08.020

16. J. Doughty, J. Soc. Welf. Fam. Law 42(3), 377-380 (2020). https://doi.org/10.1080/09649069.2020.1796221

17. J.M. Baldwin, J.M. Eassey, E.J. Brooke, Am. J. Crim. Justice 45(4), 743-758 (2020). https://doi.org/10.1007/s12103-020-09553-1

18. M. Heinsch, T. Sourdin, C. Brosnan, H. Cootes, Altern. Law J. (2020). https://doi.org/10.1177/1037969X20966147 